\title{
The use of vegetation series to assess $\alpha$ and $\beta$ vegetation diversity and their relationships with geodiversity in the province of Almeria (Spain) with watersheds as operational geographic units
}

\author{
J. J. IBÁÑEZ , R. PÉREZ-GÓMEZ , P. GANIS , \& E. FEOLI
}

\begin{abstract}
With this paper we suggest that vegetation series is a useful conceptual tool to identify a clear level of biodiversity of land systems among the many possible logical levels. The suggestion is supported by the results of a case study carried out for the province of Almeria (Spain) using the watersheds as operational geographic units. The application of standard correlation analysis, simple and partial, the Mantel's test, and the cluster analysis has shown that $\alpha$ and $\beta$ vegetation diversities, based on vegetation series, are significantly predictive with respect to environmental heterogeneity expressed by pedodiversity, lithodiversity, and some parameters of digital elevation model. Being a product of the Braun Blanquet's floristic approach, vegetation series could be the key to enter into vegetation databases for biodiversity analysis of land systems at many other levels of knowledge.
\end{abstract}

\section{Introduction}

The availability of different kinds of digital maps, describing different areas of the biogeosphere at different scales for different aims and by different features (flora, fauna, land cover, vegetation, pedology, geology, land use, etc.), that today are implemented in GIS (Geographic Information Systems) all over the world (see Dragan et al. 2007 for references) offer many opportunities to analyze the relationships between biodiversity and environmental heterogeneity at different spatial scales and at different levels of knowledge. This relationship may be studied under different perspectives useful for purposes of knowledge generation, land management, and planning.

The aim of this paper is to present the results of a study addressed to evaluate the concept of vegetation series in defining a precise level of knowledge, among many possible levels of vegetation diversity by testing its predictivity with respect to the environmental heterogeneity of land systems.

The concept of vegetation series has been recently revised by Biondi (2011), so we do not spend much more words for describing its theoretical basis. It is defined as the set of plant communities that includes different dynamical stages of the same final vegetation type of a succession. It was used to build the vegetation map of Italy (Blasi et al. 2004; Blasi 2010), to define the ecoregions in Italy (Blasi et al. 2000, 2005, 2014), and largely used to characterize landscapes in Spain (e.g. Rivas-Martínez 2005, 2007; Loidi \& Fernández-González 2012). Vegetation series would be particularly attractive for assessing vegetation diversity of land system because, being a conceptual tool developed within the Braun Blanquet's approach (i.e. a floristic approach) (van der Maarel 1975, 2005, Pignatti 1980), they could be used to have access to databases of biological properties of the species of vascular plants and therefore it would be possible to investigate on the biodiversity of land systems using different biological features (see Feoli et al. 2011 for references), according to any operational geographic units in use (OGUs, see Feoli \& Zuccarello 1996).

The study is carried out as a case study for the land system of the province of Almeria (Spain), a province that is most prone to desertification in Europe (Puigdefábregas \& Mendizabal 1998), and that, having attracted many environmental studies (see Ibáñez et al. 2015), has several available databases organized in GIS (e.g. Junta de Andalucía 2015). 
The methodology applied for the study is in line with the data mining approach since it uses available databases to answer specific questions of scientific interest that would require considerable resources of time and money to be answered if starting from scratch (e.g. Altobelli et al. 2007, Ibrahim et al. 2015).

According to Feoli et al. (2011) and Feoli (2012) the diversity of vegetation systems (corresponding to land systems that can be defined by different criteria), can be calculated in many ways and for different purposes. The terminology of $\alpha$ and $\beta$ diversity introduced by Whittaker $(1960,1975,1977)$, respectively, for species diversity of a plant community and of a set of plant communities (of a given landscape or a vegetation system), can be extended for objects (features) different from species, and collections (sets) of objects different from plant communities. The concept of diversity is in fact used in many disciplines from chemical physical ones (e.g. Riemer \& West 2013) to geological ones (e.g. Gray 2004, Ibáñez \& Bockheim 2013) to socioeconomic ones (Ottaviano et al. 2003) where the units for measuring diversity are different from those of individual plants (or animals).

Notwithstanding Feoli et al. $(1988,2011)$ and Feoli (2012) suggest that the concept of $\beta$ diversity is misleading, because it does not consider explicitly the two components of the technical definition of diversity, namely richness and the evenness, in this paper we use is not only because it became so "popular" in the ecological jargon, that it would be difficult to communicate within the field of biodiversity without using it (see Manthey \& Fridley 2009, Anderson et al. 2011, Tuomisto 2011, Podani \& Schmera 2016 for references), but because $\alpha$ diversity may be interpreted in terms of $\beta$ diversity (similarity/dissimilarity) according to similarity theory (Feoli \& Orlóci 2011). In this respect, Feoli (2012) and Feoli et al. (2013) while proposing to classify diversity measures as crispy and fuzzy ones, have shown that the wellknown indices of Gini-Simspon and Shannon, used to calculate the crispy a diversity are, respectively, the average similarity between the $Q$ units (individuals of plant or animal, grams, $\mathrm{kg}$, joules, square meters, etc.) described by their belonging ( 1 or 0 ) to a given collection (set) of different $N$ objects (plant species, animals, land cover type, plant associations, pedotypes, etc.) in a matrix $\mathbf{X}(N, Q)$, and the entropy of the eigenvalues of the similarity matrix $\mathbf{S}(Q, Q)$ between the $Q$ units of the matrix $\mathbf{X}(N, Q)$. It follows that $\alpha$ diversity is a similarity/dissimilarity, crispy or fuzzy, between the set of units defined by the objects within a collection i.e. a $\beta$ diversity of the first level. According to Feoli et al. (1988), to be consistent with the definition of diversity, $\beta$ diversity should be the $\alpha$ diversity, crispy or fuzzy, of a collection of collections of objects (i.e. at a higher hierarchical level than that of $\alpha$ diversity) calculated with the algorithms used for a diversity, but this is not considered in the current literature where the $\beta$ diversity is a mere measure of similarity/dissimilarity between collections of objects. It is clear that in such circumstances of inconsistency of terminology and with so many possibilities to calculate $\alpha$ and $\beta$ diversity, it is very important always to clearly define the objects, the units to quantify, or weigh the objects and then the collections. In vegetation diversity analysis the basic objects are species or plant communities (Feoli 2012). However species and plant communities may define different levels of knowledge on which to base the measurement of biodiversity. Species may be described by several characters (taxonomic-phylogenetic, cytogenetic, functional-morphological, etc.) in matrices $\mathbf{X}(k, s)$ where $k$ are the characters and $s$ is the species, while the objects (relevés, set of relevés, list of species of given areas, etc.) may be described in matrices $\mathbf{X}(s, N)$ where s are the species and $N$ is the number of the objects. A simple matrix multiplication of the two matrices may transform the description of objects in another description (see Feoli et al. 2011, for references) i.e. to a new level of knowledge. The units for the species are the plant individuals, or units of their land cover measured in $\mathrm{m}^{2}, \mathrm{~km}^{2}$, etc., or units of biomass ( $\mathrm{g}, \mathrm{kg}$, etc.), while the units for plant communities are generally the $\mathrm{m}^{2}$ or $\mathrm{km}^{2}$ in which their land cover is measured. The collections always include pieces of lands called OGUs (see Feoli \& Zuccarello 1996). Such pieces of land correspond to "relevés" in case of species diversity of plant communities, or pieces of land corresponding to polygons of various size when dealing with plant community diversity of a land system. Also in this case, as in the case of species, it is possible to define several levels of knowledge according to the way the plant communities are described. Vegetation series, for example is a level which corresponds to a set of plant communities included in the same process of succession. It is not a syntaxon such association, alliance, order, or class, but a set of dynamical stages that could include different syntaxa.

We have chosen the watersheds as OGUs of the study because they are land systems with natural boundaries that can be objectively defined, they have different extent, and an inherent different environmental heterogeneity that is due at least to a gradient of elevation (Troch et al. 2008; Wen et al. 2011). According to Omernik and Bailey (1997) “... no two watersheds are alike, regarding their quality and quantity of water and mosaic of ecosystem components ...". Thanks to these facts watersheds can be used to study the $\alpha$ diversity of vegetation seriesarea relationships (see Feoli et al. 2013) by removing the effects of different kind of environmental heterogeneity in analogy to what was proposed by Ibáñez 
et al. (2014) for studying the relationships plant species richness - area with the countries of the world as OGUs and the pedodiversity as expression of environmental heterogeneity. Watersheds can be also used to study the $\beta$ diversity of land systems when they include many watersheds according to the "philosophy" of trying to investigate the "homogeneity of heterogeneities" well explained by Saldaña (1997). Literature on the use of watershed for regionalization and classification of small or large geographical areas for environmental management and biological conservation purposes is relatively rich (e.g. Olivero et al. 2013), however the key points have been largely discussed in Warren (1979), Rao and Srinivas (2008), and Potyondy and Geier (2011).

\section{The study area}

The study area covers the great part of the Almeria Province located in South-Eastern part of the Iberian Peninsula with an approximate extent of $7726.75 \mathrm{~km}^{2}$ on a total area of $8769.05 \mathrm{~km}^{2}$. It consists of 19 watersheds according to the Spanish National Geographic Institute (www.ign.es) (Figure 1).

The aridity of the province is the result of physiographic natural conditions and a millenary land use (see Brandt \& Thornes 1996). The physiography of the area is very steep, reaching over short distances up to $3000 \mathrm{~m}$ from sea level (Simón 2005). The climate is arid, increasing precipitation from $800 \mathrm{~m}$ at the mountain tops. Mediterranean forests only appear from the middle up the mountain peaks, where appear the typical humid meadows and shrubs of this biome (Simón 2005). Low land depressions are rich in arid landforms such as badlands, alluvial fans, endorheic basins covered by salt crust or gypsum, playas, etc. (Cooker \& Warren 1973; Ollier 1976; Villalobos-Megía 2003), whereas in coastlands, dunes, marine terraces, wetlands, ephemeral fluvial courses called "Ramblas," saltmarshes and sands beaches are common. Mountain slopes are covered by shallow and weakly developed soils (e.g. Regosols \& Leptosols), whereas the soil mantle of lowlands is representative of arid environments, with



Figure 1. Map of the province of Almeria with the indication of the 19 watersheds. 
Calcisols, Solonchaks, and Gypsisols (Aguilar-Ruiz et al. 2004). All watersheds have the main river reaching the sea, so all the watersheds include vegetation series that are typical of coastal areas, however not all the watersheds are so large to include mountain areas with vegetation series that are typical of the Mediterranean mountains. Each watershed was assigned a rank according the Horton-Strahler method (Strahler 1957) which represents its stream order or branching complexity (rank between 1 and 4 in the study area, Table I).

\section{Data}

The data of our study consist of 4 matrices: $\mathbf{V}(V, N)$, $\mathbf{S}(S, N), \mathbf{L}(L, N)$, and $\mathbf{E}(E, N)$ that, respectively, describe the 19 watersheds $(N)$ of the land system of Almeria by the extent of vegetation series, pedotypes, lithotypes and the maximum, average and standard deviation of elevation of the digital elevation model (DEM) (variability of elevation) and one vector $\mathbf{A}(1, N)$ describing the watersheds by their extent in $\mathrm{Km}^{2}$. The matrices $\mathbf{V}(V, N)$ and $\mathbf{L}(L, N)$ have been obtained by GIS technology using the digital maps of vegetation series (at scale 1:10,000) and lithotypes (at scale 1:400,000) stored in the Spatial Data Infrastructure of Andalusia Portal (Junta de Andalucía 2015). The vegetation series (V) are 40, the lithotypes $(L)$ are 17. The matrix $\mathbf{S}(S, N)$ has been obtained by the digital soil map (44 pedotypes (S), at scale 1:100,000) produced by Aguilar-Ruiz et al. (2004) according to the World Reference Base for Soil Resources soil classification (FAO 1998). The matrix $\mathbf{E}(E, N)$ and the vector $\mathbf{A}(1, N)$ were obtained by the DEM. The considered parameters $(E)$ are three (the maximal, the average, and the standard deviation of elevation). The pixel size for DEM resolution is $25 \mathrm{~m}$ (1 $\mathrm{mm}$ at $25.000 \mathrm{scale}$ ). The original data of DEM were downloaded from the "Instituto Geográfico Nacional" website (http://www.ign.es) that is the National Mapping Agency in Spain.

\section{Methods}

\section{The basic assumptions}

The methods are addressed to test for predictivity (i.e. the capacity of prediction) of $\alpha$ and $\beta$ "vegetation series" diversity, respectively, with respect to within and between environmental heterogeneity of the watersheds of the Almeria's province.

A good predictivity would mean that the heterogeneity expressed by vegetation series is correlated with the environmental heterogeneity. The basic assumptions of the methodology applied in this study are very simple and can be formulated as follows:
(1) the $\alpha$ diversities based on vegetation series, pedotypes, lithotypes, and the variability of elevation are expressions of environmental heterogeneity within the watersheds

(2) the $\beta$ diversity of vegetation series, pedodiversity, lithodiversity, and DEM (i.e. the similarity/dissimilarity between the watersheds) are expression of heterogeneity between the watersheds and therefore of the heterogeneity of the whole land system of Almeria.

\section{The methodology}

According to the basic assumptions, the evaluation of the predictivity of vegetation series with respect to environmental heterogeneity based on pedotypes, lithotypes, and DEM has been carried out by answering the three following questions:

(1) Is $\alpha$ vegetation diversity of the watersheds based on vegetation series correlated to the heterogeneity expressed by the $\alpha$ diversity of pedotypes, lithotypes (i.e. $\alpha$ pedodiversity and $\alpha$ lithodiversity) and to the variability of elevation of their DEMs?

(2) Is the matrix of similarity between the watersheds in terms of vegetation series, correlated with the matrices of similarity between the watersheds based on pedo- and lithotypes and DEM? Or in other terms, is the $\beta$ vegetation diversity of watersheds correlated with the $\beta$ diversity of the watersheds calculated by pedotypes, lithotypes, and DEM?

(3) Is the classification of the watershed based on vegetation series predictive with respect to the heterogeneity of the land systems?

In this paper, only the crispy diversities are considered, because we do not consider the similarity/dissimilarity between the $N^{1}$ objects of a single $i$ th collection in terms of some of the many possible characters by which they could be described beside the proportions of the $Q$ units (e.g. Rao 1982, see Feoli 2012). Therefore the $\alpha$ diversity of the given $i$ th watershed is given by the richness $\left(N^{1}\right)$ and/or as the combination of richness and the proportions (evenness) of the $N^{1}$ set of features in the $i$ th watershed, while the $\beta$ diversity by the similarity-dissimilarity between different watersheds as described by the different features (vegetation series, pedotypes, lithotypes, and parameters of DEM).

The methods used to answer the three questions are described as follows. 
Question 1. The steps of the analysis are the following:

(1) The $\alpha$ diversity of watersheds has been calculated with the matrices $\mathbf{V}(V, N), \mathbf{S}(S, N), \mathbf{L}(L, N)$ both by the richness (number of features) and by Shannon and Weaver (1949) entropy, routinely used to calculate the $\alpha$ diversity of landscapes mosaics (see Turner 1990; Farina 2000 for details).

(2) Simple correlation has been carried out between the $\alpha$ vegetation diversity, the richness and the entropy of pedotypes and lithotypes ( $\alpha$ diversities), the standard deviation of elevation and the area of watersheds, using both the original area in $\mathrm{Km}^{2}$ and its logarithmic transformation.

(3) First-order partial correlation analysis (see Kleinbaum et al. 1988) has been carried out to test which parameter among area, pedodiversity, lithodiversity, and standard deviation of elevation is the most important to define the $\alpha$ vegetation diversity of the watersheds. The differences between the simple correlation and the partial correlation offer a measure of such efficiency.

To perform partial correlation analysis we have used the online calculator of Wessa (2015).

Question 2. The steps of the analysis are the following:

(1) For the three matrices $\mathbf{V}(V, N), \mathbf{S}(S, N), \mathbf{L}(L, N)$ we have applied a preliminary test for measuring if they are significantly nested in order to choose an appropriate similarity function for comparing the watersheds. Nestedness (Ulrich et al. 2009; Podani \& Schmera 2011, 2012; Almeida-Neto et al. 2012; Ulrich \& Almeida-Neto 2012; Podani et al. 2013) is realized when a set of characters describing one object is completely included in the set of characters describing another one. This commonly occurs in island biogeography when on the basis of species of plants or animals, small islands are compared with big islands of the same archipelagos. In such circumstances, the differences may be due only because by chance the larger islands have more environmental heterogeneity than the smaller ones, or because at the same level of heterogeneity the bigger islands have more resources available for a great number of species. The smaller watersheds could be different from the bigger ones in terms of vegetation series, pedotypes, lithotypes, and elevation variability only because, by chance, they are missing environmental conditions that they would have in case they would be bigger. To test for nestedness the well-known method of temperature metrics (low temperature high nestedness) has been applied directly to the matrices $\mathbf{V}(V, N)$, $\mathbf{S}(S, N)$, and $\mathbf{L}(L, N)$ (Patterson 1990; Atmar \& Patterson 1993, 1995; Ibáñez et al. 2005b).

(2) Since the matrices resulted significantly nested the similarity between the watersheds was calculated by the index of Simpson (1943). Given two watersheds the index is given by the ratio between the number of features the two watersheds have in common and the number of features of the less richer one among the two. In general terms, according to this index the similarity between two OGUs is 1 (maximal similarity) when the two OGUs are equal or when the set of characters describing one of them includes completely the set of the other one. It follows that a completely nested matrix would be a completely homogeneous matrix that would not give indication of a possible classification. The Euclidean distance (D) was used to calculate the similarity between the watersheds described by the maximal, average, and standard deviation of the elevation and the similarity between the watersheds on the basis of their extent.

(3) The Mantel's test (Mantel 1967; Mantel \& Valand 1970) has been used to measure the correlation between the five similarity/dissimilarity matrices obtained by the Simpson,s index: $\mathbf{S V}(N, N) \mathbf{S S}(N, N), \mathbf{S L}(N, N), \operatorname{DE}(N, N)$, and $\operatorname{DA}(N, N)$.

Question 3. The steps of the analysis are the following:

(1) Cluster analysis by single, average, and complete linkage (Anderberg 1973; Podani 2000) has been applied to the symmetric matrix $\mathbf{S V}(N, N)$.

(2) With the matrix $\operatorname{SV}(N, N)$, we have tested the optimal classification, e.g. the maximal separation between the clusters at different hierarchical levels, by the method suggested by Burba et al. (2008) and Feoli et al. (2009). This consists in calculating the evenness of the eigenvalues of the within-between similarity matrices obtained by averaging the similarity scores of the similarity matrix, in this case $\mathbf{S V}(N, N)$, according to the clusters defined at different hierarchical levels of the dendrogram, and in testing the significance of the evenness by a permutation technique.

(3) The clusters and the largest watersheds described by the presence absence of vegetation series have been compared by the probability of similarity according to Pillar (1996) using the similarity ratio as index of similarity (Wishart 1969).

(4) The predictivity of the classification of watersheds based on vegetation series with respect to 
pedology and lithology, and the DEM has been tested by the evenness test applied to the matrices $\mathbf{S S}(N, N), \mathbf{S L}(N, N)$ and $\mathbf{S E}(N, N)$ by superimposing to them the classification obtained with matrix $\mathbf{S V}(N, N)$. The matrix $\mathbf{S E}(N, N)$ is a similarity matrix obtained by a transformation of the values of matrix $\operatorname{DE}(N, N)$ between 1 and 0 (where 1 is the maximal similarity, corresponding to Euclidean distance $=0$, and 0 is the minimal similarity corresponding to the maximal Euclidean distance in $\mathbf{D E}(N, N)$ ).

To answer the questions 2 and 3 the program MATEDIT (Burba et al. 2008) was used.

\section{Results}

Table I presents the results of $\alpha$ diversity analysis, i.e. it gives the richness of the 19 watersheds according to lithotypes, pedotypes, and vegetation types and the Shannon entropy calculated by the proportional area of the three features. It gives also the standard deviation of elevation of each watershed as a measure of variability of elevation within the watersheds.

In Table I the watersheds are arranged by their extent. The correlation between the $\alpha$-diversities of watersheds with their Hortonian rank, their extent and the standard deviation of elevation is given in Table II, according to the Pearson correlation coefficient (only $r>0.457$ is significant at probability $p<0.05)$.

The majority of correlations are significant. From Table II it is clear that the correlation between the diversity parameters and the area increases when considering the logarithmic transformation of the area $(\ln ($ area $))$. This suggests that the correlation between the area and diversity parameters is not linear, but rather follow a non-linear strong monotonic trend in agreement with the results of previous papers (e.g. Ibáñez et al. 2005a, 2014; Ibáñez \& Effland 2011; Ibáñez \& Feoli 2013). By considering the correlation coefficients between the $\ln$ (area) and the four features, the area shows the highest influence on the pedodiversity $(S)$ and the lowest on standard deviation of elevation (i.e. $r(V, A)=0.80, r(S, A)=0.95, r(L, A)=0.73$, $r(E, A)=0.58)$. This means that as the area of watersheds increases the heterogeneity expressed by pedodiversity is the one that increases more, followed by vegetation series, lithodiversity, and the one of DEM (i.e. small watersheds may have high variability in elevation).

Table I. Description of the watersheds of the province of Almeria ordered according to their extent (area).

\begin{tabular}{lcrrrrrrrrr}
\hline $\mathrm{W}_{\text {code }}$ & $\mathrm{HR}$ & Area & $\mathrm{Ln}_{\text {(area) }}$ & $\mathrm{R}_{\mathrm{veg}}$ & $\mathrm{R}_{\mathrm{s}}$ & $\mathrm{R}_{\text {lit }}$ & $\mathrm{SH}_{\text {veg }}$ & $\mathrm{SH}_{\mathrm{s}}$ & $\mathrm{SH}_{\text {lit }}$ & \multicolumn{1}{c}{$\mathrm{sd}(\mathrm{ele})$} \\
\hline 101 & 1 & 26.5 & 3.277 & 5 & 4 & 3 & 1.12 & 1.11 & 0.39 & 199.67 \\
111 & 1 & 32.7 & 3.487 & 3 & 8 & 6 & 0.03 & 1.66 & 0.96 & 48.85 \\
109 & 1 & 37.1 & 3.614 & 5 & 8 & 4 & 1.12 & 1.31 & 1.15 & 80.24 \\
106 & 1 & 38.1 & 3.640 & 9 & 12 & 5 & 1.81 & 1.60 & 0.93 & 364.94 \\
102 & 1 & 39.9 & 3.686 & 6 & 8 & 4 & 1.18 & 1.68 & 1.30 & 265.43 \\
105 & 1 & 50.9 & 3.930 & 9 & 12 & 5 & 1.65 & 1.62 & 1.32 & 302.98 \\
110 & 1 & 55.4 & 4.015 & 7 & 17 & 5 & 0.91 & 2.24 & 1.26 & 151.15 \\
107 & 1 & 55.6 & 4.018 & 9 & 12 & 5 & 0.68 & 1.52 & 0.69 & 189.48 \\
112 & 1 & 61.6 & 4.121 & 4 & 8 & 6 & 0.71 & 1.75 & 0.79 & 80.02 \\
104 & 1 & 74.8 & 4.315 & 6 & 13 & 6 & 1.04 & 1.86 & 1.13 & 376.34 \\
108 & 1 & 178.8 & 5.186 & 8 & 19 & 4 & 1.10 & 2.18 & 0.95 & 93.04 \\
203 & 2 & 264.1 & 5.576 & 6 & 19 & 12 & 0.91 & 2.15 & 1.37 & 230.90 \\
201 & 2 & 350.7 & 5.860 & 15 & 19 & 8 & 1.33 & 1.96 & 1.73 & 219.56 \\
301 & 3 & 368.7 & 5.910 & 12 & 20 & 8 & 1.73 & 2.19 & 1.90 & 586.51 \\
302 & 3 & 403.5 & 6.000 & 11 & 19 & 6 & 1.09 & 2.03 & 2.02 & 228.35 \\
202 & 2 & 492.4 & 6.199 & 9 & 24 & 11 & 1.46 & 2.07 & 1.55 & 204.22 \\
103 & 1 & 725.0 & 6.586 & 12 & 21 & 6 & 1.63 & 2.12 & 1.54 & 508.27 \\
401 & 4 & 2025.4 & 7.614 & 24 & 29 & 9 & 1.86 & 2.35 & 1.91 & 486.69 \\
303 & 3 & 2445.3 & 7.802 & 15 & 31 & 11 & 1.89 & 2.21 & 1.43 & 440.94 \\
\hline
\end{tabular}


tion series, of pedotypes and lithotypes, $\mathrm{SH}_{\mathrm{veg}}, \mathrm{SH}_{\mathrm{s}}, \mathrm{SH}_{\mathrm{lit}}=$ entropy by Shannon formula for vegetation series, pedotypes and lithotypes, $\operatorname{sd}(\mathrm{ele})=$ standard deviation of elevation.

Table II. Correlation coefficients between variables in Table I.

\begin{tabular}{lcccccccccc}
\hline & $\mathrm{HR}$ & $\mathrm{Area}$ & $\mathrm{Ln}(\mathrm{area})$ & $\mathrm{R}_{\text {veg }}$ & \multicolumn{1}{c}{$\mathrm{R}_{\mathrm{s}}$} & $\mathrm{R}_{\text {lit }}$ & $\mathrm{SH}_{\text {veg }}$ & $\mathrm{SH}_{\mathrm{s}}$ & $\mathrm{SH}_{\text {lit }}$ & $\mathrm{sd}(\mathrm{ele})$ \\
\hline $\mathrm{HR}$ & 1 & 0.751 & 0.815 & 0.791 & 0.765 & 0.661 & 0.487 & 0.607 & 0.759 & 0.531 \\
Area & 0.751 & 1 & 0.843 & 0.7842 & 0.813 & 0.595 & 0.564 & 0.549 & 0.466 & 0.545 \\
Ln(area) & 0.815 & 0.843 & 1 & 0.8056 & 0.95 & 0.738 & 0.571 & 0.787 & 0.73 & 0.582 \\
$\mathrm{R}_{\text {veg }}$ & 0.791 & 0.784 & 0.806 & 1 & 0.789 & 0.441 & 0.691 & 0.573 & 0.667 & 0.651 \\
$\mathrm{R}_{\text {s }}$ & 0.765 & 0.813 & 0.95 & 0.7887 & 1 & 0.743 & 0.582 & 0.86 & 0.705 & 0.546 \\
$\mathrm{R}_{\text {lit }}$ & 0.661 & 0.595 & 0.738 & 0.4412 & 0.743 & 1 & 0.287 & 0.633 & 0.541 & 0.344 \\
SH $_{\text {veg }}$ & 0.487 & 0.564 & 0.571 & 0.6912 & 0.582 & 0.287 & 1 & 0.327 & 0.489 & 0.775 \\
SH $_{\text {s }}$ & 0.607 & 0.549 & 0.787 & 0.573 & 0.86 & 0.633 & 0.327 & 1 & 0.702 & 0.424 \\
SH $_{\text {lit }}$ & 0.759 & 0.466 & 0.73 & 0.6669 & 0.705 & 0.541 & 0.489 & 0.702 & 1 & 0.531 \\
sd(ele) & 0.531 & 0.545 & 0.582 & 0.651 & 0.546 & 0.344 & 0.775 & 0.424 & 0.531 & 1 \\
\hline
\end{tabular}


The results of partial correlation analysis using the log transformation for the area and letting the other data untransformed are the following:

(1) The correlation between vegetation $\alpha$ diversity $(y)$ and the area $(x)\left(r^{\mathrm{yx}}=0.81\right)$, by removing the effect of pedodiversity $(z)$ becomes $r^{\mathrm{yx} / \mathrm{z}}=0.29$, $T=1.2, p>0.05$ (not significant).

(2) The correlation between vegetation diversity $(y)$ and area $(x)\left(r^{y x}=\right.$ by removing the effects of standard deviation of elevation $(z)$ becomes $r^{\mathrm{vx} \mid \mathrm{z}}=0.69, T=3.83, p<0.01$, (significant).

(3) The correlation between vegetation diversity $(y)$ and the area $(x)\left(r^{y x}=0.80\right)$, by removing the effect of lithodiversity $(z)$ becomes $r^{y x}{ }^{y}=0.79$, $T=5.1, p<0.001$ (significant).

(4) The correlation between vegetation diversity (y) and pedodiversity $(x)\left(r^{\mathrm{yx}}=0.79\right)$, by removing the effect of area (z) becomes $r^{\mathrm{y} \times \mid z}=0.13$, $T=0.53, p>0.05$ (not significant).

(5) The correlation between vegetation diversity $(y)$ and pedodiversity $(x)(r y x=0.79)$ by removing the effect of standard deviation of elevation (z) becomes $r^{\mathrm{yx} \mid z}=0.68, T=3.8, p<0.01$ (significant).

(6) The correlation between vegetation diversity $(y)$ and pedodiversity $(x)\left(r^{\mathrm{yx}}=0.79\right)$ by removing the effect of lithodiversity becomes $r^{y \mathrm{x}} \mathrm{z}=0.76$, $T=4.9, p<0.001$ (significant).

(7) The correlation between vegetation diversity $(y)$ and standard variation of elevation $(x)$ $\left(r^{\mathrm{yx}}=0.65\right)$ by removing the effects of the area becomes $r^{\mathrm{xy} z}=0.38, T=1.76, p>0.05$ (not significant).

(8) The correlation between vegetation diversity $(y)$ and standard deviation of elevation $(x)$ $\left(r^{\mathrm{yx}}=0.65\right)$ by removing the effect of pedodiversity $(z)$ becomes $r^{\mathrm{xy}}=0.427, T=1.85$, $p>0.05)$ (not significant).

(9) The correlation between vegetation diversity $(y)$ and standard deviation of elevation $(x)$ $\left(r^{\mathrm{vx}}=0.65\right)$ by removing the effect of lithodiversity becomes $r^{\mathrm{vx}} \mathrm{z}=0.59, T=4.59, p<0.01$ (significant).

(10) The correlation between the vegetation diversity $(y)$ and lithodiversity $(x)\left(r^{\mathrm{yx}}=0.44\right)$ by removing the effect of the area $(z) r^{\mathrm{y} \times \mathrm{z}}=-0.38$, $T=1.76, p>0.05$ (not significant).

(11) The correlation between vegetation diversity $(y)$ and lithodiversity $(x)\left(r^{y x}=0.44\right)$ by removing pedodiversity $(z)$ becomes $r^{\mathrm{yx} \mid \mathrm{z}}=-0.35$, $T=1.36, p>0.05$ ) (not significant)

(12) The correlation between vegetation diversity $(y)$ and lithodiversity $(\mathrm{x})\left(\mathrm{r}_{\mathrm{yx}}=0.44\right)$ by removing the effect of standard deviation of elevation (z) becomes $r^{\mathrm{yx} \mid \mathrm{z}}=0.30, T=1.2, p>0.05$ ) (not significant)
From these results, it is clear that $\alpha$ vegetation diversity of the watersheds based on vegetation series is defined mainly by the synergic effects of the extent of the area and pedodiversity, since by removing the effects of the area the correlation between vegetation diversity and pedodiversity becomes not significant, as it happens when removing the effects of pedodiversity in the correlation between vegetation diversity and area. The effects of the variability in elevation expressed by the standard deviation of elevation and of lithodiversity look less significant in defining the vegetation $\alpha$ diversity since by removing their effects, the correlations between vegetation diversity-area and vegetation diversity - pedodiversity remain significant.

The results of the nested subset analysis according to Atmar and Patterson (1993) using their statistical software termed "The nestedness temperature Calculator" (Atmar \& Patterson 1995) are presented in Table III.

The Mantel's test applied to the matrices of similarity between the watersheds, shows that there is a significant correlation between matrices $\mathrm{SV}(N, N)$ and $\operatorname{DE}(N, N)(r=-0.42, p<0.0001), \mathrm{SV}(N, N)$ and $\mathbf{S S}(N, N)(r=0.35 p<0.0001)$, and $\mathbf{S S}(N, N)$ and $\mathbf{S L}(N, N)(r=0.30 p<0.0001)$ but not between the matrices $\mathbf{S V}(N, N)$ and $\mathbf{S L}(N, N)(r=0.11$, $p=0.14)$. We can conclude that there is a positive correlation between the combination of vegetation series and the combination of the three parameters of the DEM (maximal elevation, average elevation, and standard deviation of elevation) and between the combination of vegetation series and the combination of pedotypes, but not between the combination of vegetation series and the combination of lithotypes. The values of $r$ suggest that $\beta$ vegetation diversity (i.e. the variation in watersheds in terms of vegetation series combination in the watersheds) is more affected by the combination of values of the three parameters of elevation of the DEM rather than to the combination of pedotypes, this would mean that the vegetation series combination in the watersheds would be affected firstly by the microclimatic conditions related to the DEM that certainly have direct effects on the heterogeneity of microclimate, and then by the factors controlling the combination of pedotypes (heterogeneity of pedosphere). The fact that vegetation $\beta$ diversity is correlated with $\beta$ pedodiversity and not with $\beta$ lithodiversity is

Table III. Results of the nestedness analysis by the method of temperature of Atmar and Patterson (1995).

\begin{tabular}{lccc}
\hline Matrices & ST & MF & $p$ \\
\hline $\mathbf{V}(V, N)$ & 21.4 & 23 & $<0.00001$ \\
$\mathbf{S}(S, N)$ & 17.5 & 34.6 & $<0.00001$ \\
$\mathbf{L}(L, N)$ & 23 & 38 & $<0.00001$ \\
\hline
\end{tabular}

Note: $\mathrm{ST}=$ system temperature, $\mathrm{MF}=$ matrix fill, $p=$ probability. 
certainly a consequence of the fact that the vegetation has a direct contact with the pedosphere and only indirectly with lithosphere.

The classification of watersheds based on the matrix $\mathbf{S V}(N, N)$ has given (with average and complete linkage methods) 2 main clusters with exactly the same content. The two main clusters (Figure 2) are:

cluster 1) $101,102,103,104,105,106,107,301$, 401 ;

cluster 2) $108,109,110,111,112,201,202,203,302,3$ 03.

According to the method suggested by Feoli et al. (2009) (i.e. the evenness of the eigenvalues of the matrices within-between cluster similarity as defined at different hierarchical level of the dendrograms) the classification based on matrix $\mathbf{S V}(N, N)$ is highly significant. For 2 clusters the evenness is 0.76 , for three clusters it is 0.72 , for 4 clusters it is 0.66 , for 5 clusters it is 0.65 , both using average and complete linkage clustering algorithms. The single linkage produces a chained dendrogram from which it is difficult to identify directly a clear hierarchical pattern, in any case the two largest watersheds (401 and 303) are well separated in the dendrogram.

According to this result, the land system of Almeria can be classified in two main clusters of watersheds as in Figure 3, one facing the southwest
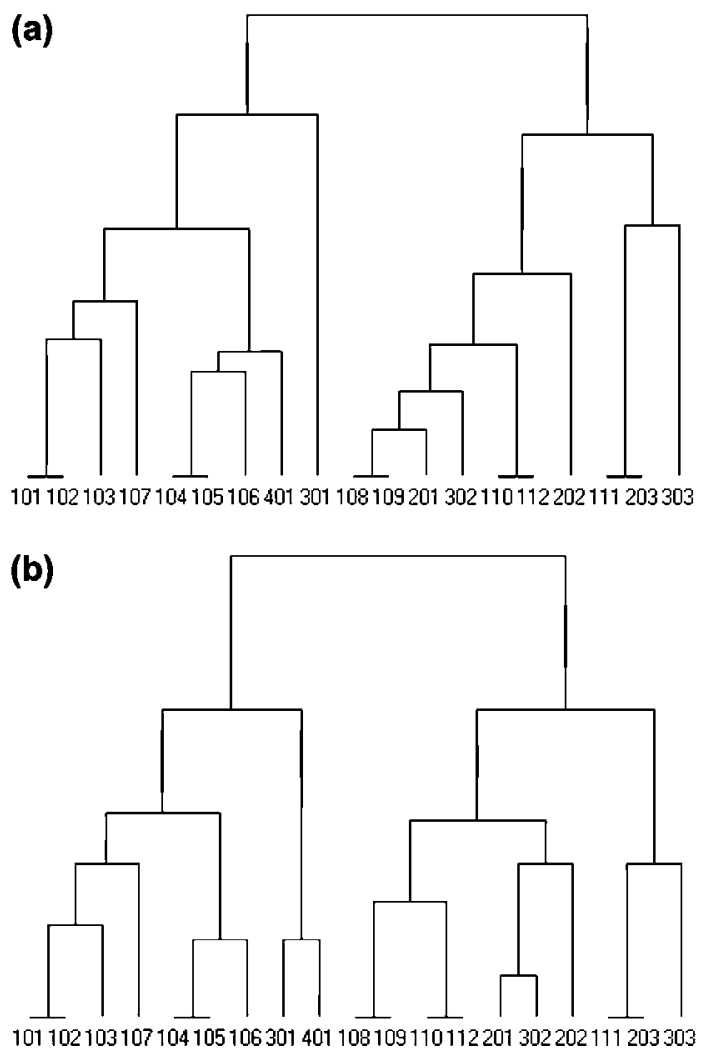

Figure 2. Dendrograms of cluster analysis of watersheds by average a) and complete linkage b) methods applied to the Simpson's similarity matrix. coast of Almeria $(101,102,103,104,105,106,107$, $301,401)$ the other facing the southeast coast (108, $109,110,111,112,201,202,203,302,303$ ) as in Figure 3 . If the largest watersheds (401 and 303) are removed, the classification of the remaining watersheds is the same. This suggests that there is a natural boundary between the cluster containing the watershed 401 and the cluster containing the watershed 303 , that is the line following the top of the mountain chain separating the two watersheds (Figure 4).

Table IV presents the description of the clusters $(\mathrm{C} 1 \mathrm{~V}, \mathrm{C} 2 \mathrm{~V})$ by the frequency of vegetation series, the table also presents the combination of vegetation series of the largest watersheds (401 and 303) and also the description of the clusters $\mathrm{C} 1 \mathrm{~V}$ and $\mathrm{C} 2 \mathrm{~V}$, by the frequency of vegetation series without the watersheds 401 and 303 (i.e. 301_107 and 108_302). The probability of similarity between $\mathrm{C} 1 \mathrm{~V}$ and $\mathrm{C} 2 \mathrm{~V}$ is 0.26 , the probability of similarity between watershed 401 and 303 is 0.22 , and the probability of similarity between the clusters 301_107 and 108_302 is 0.10 . This means that the classification is significantly sharp and that the two clusters are justified in terms of vegetation series composition. From Table IV the thermo-Mediterranean series result more concentrated in the second cluster $(\mathrm{C} 2 \mathrm{~V})$ while in the first (C1V) there is a higher concentration of the meso-Mediterranean series and also an higher concentration of vegetation series of rich soils. Owing to the use of the Simpson similarity index there is no statistical difference between the two clusters in terms of a diversity of vegetation, pedology, and lithology. The classification of the watersheds based on vegetation series is significantly predictive with respect to all three other features (pedotypes, lithotypes, and variability of elevation). By superimposing the classification to the matrices $\mathbf{S S}(N, N), \mathbf{S L}(N, N)$ and $\operatorname{SE}(N, N)$ the evenness test of the eigenvalues is significant in all the three cases (respectively $E(S)=0.24 p=0.0146, E(L)=0.256 p=0.035$, and $E(E)=0.248, p=0.024)$, this means that vegetation series combinations in the watersheds are predictive with respect to the combination of the other features.

\section{Discussion}

Vegetation series is a conceptual tool that is widely used to produce maps of potential vegetation in some countries of Europe, mainly Italy and Spain. The fact that such maps are stored in GIS would facilitate their use for further studies concerning the biodiversity of land systems at one level of knowledge in vegetation sciences, i.e. the level of vegetation series. We have assumed that the predictivity of vegetation series diversity would be higher with respect to other environmental heterogeneities such as those 


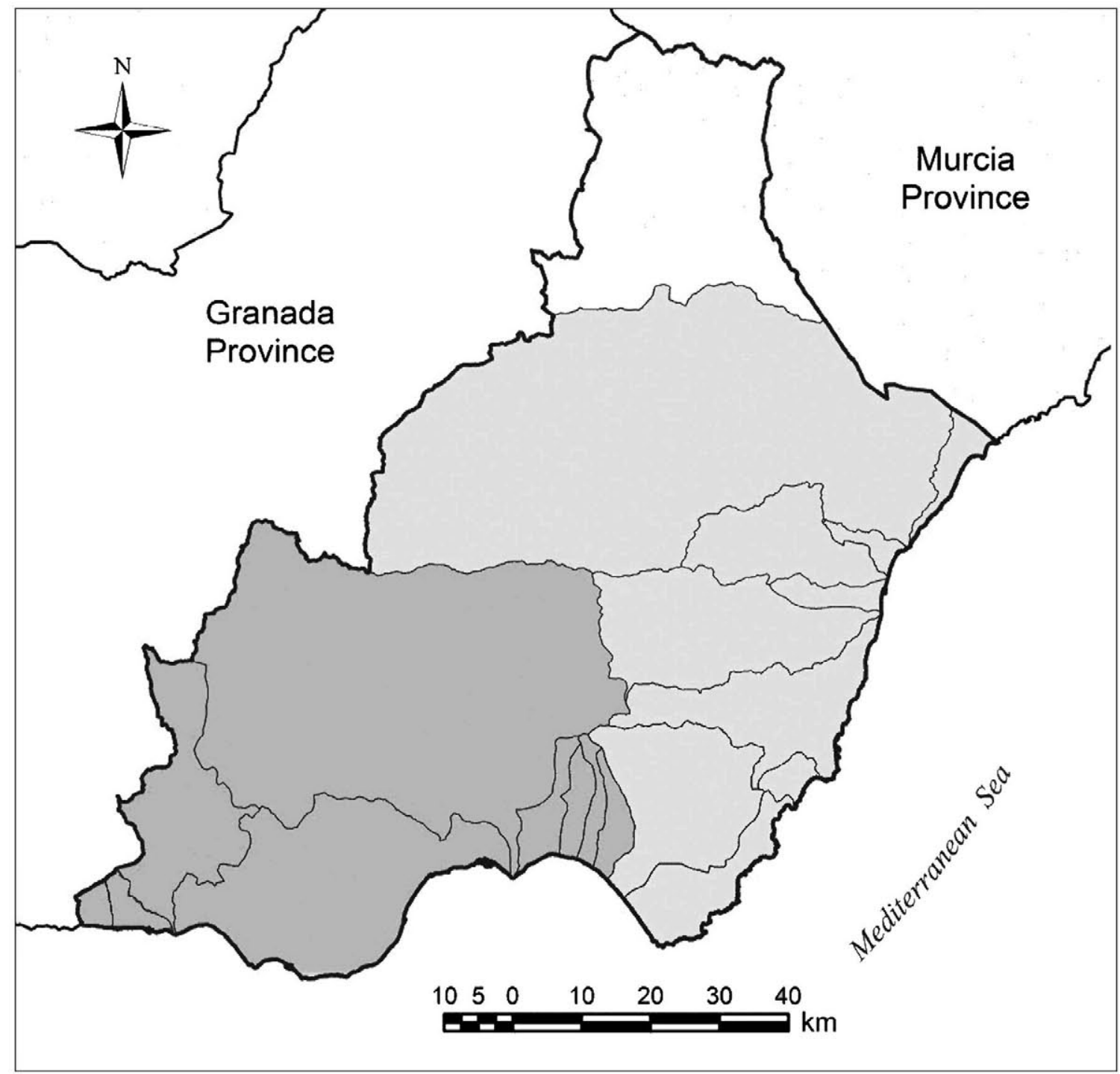

Figure 3. Map of the classification of the watersheds in two clusters according to Figure 2.

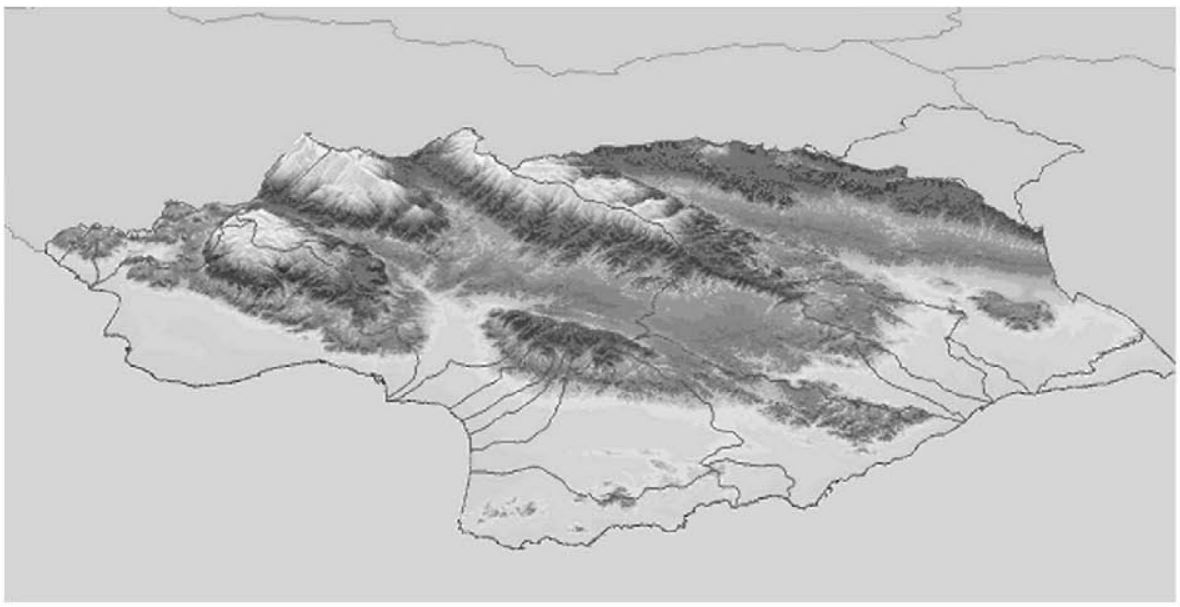

Figure 4. Digital elevation model of the province of Almeria with indication of the watersheds boundaries. 
Table IV. Frequencies of vegetation series in the two clusters (C1V and $\mathrm{C} 2 \mathrm{~V})$, presence (1) and absence $(0)$ of vegetation series in the largest watersheds (401 and 303) and frequency of watersheds in the clusters $\mathrm{C} 1 \mathrm{~V}_{(\mathrm{w})}$ and $\mathrm{C} 2 \mathrm{~V}_{(\mathrm{w})}$ without the watersheds 401 in $\mathrm{C} 1 \mathrm{~V}$ and 303 in $\mathrm{C} 2 \mathrm{~V}$.

\begin{tabular}{|c|c|c|c|c|c|c|}
\hline Vegetation series & $\mathrm{C} 1 \mathrm{~V}$ & $\mathrm{C} 2 \mathrm{~V}$ & 401 & 303 & $\mathrm{C}_{1} \mathrm{~V}_{(w)}$ & $\mathrm{C} 2 \mathrm{~V}_{(w)}$ \\
\hline Brackish waters edaphohygrophilous geoseries & 0.8 & 0.7 & 0 & 0 & 0.9 & 0.8 \\
\hline Coastal dunes \& sand deposits vegetation & 0.4 & 0.4 & 0 & 0 & 0.5 & 0.4 \\
\hline Edaphoxerophilous on gypsum vegetation complex & 1 & 0 & 1 & 0 & 1 & 0 \\
\hline Gypifeous edaphoxerophilous vegetation complex & 0.6 & 0 & 1 & 0 & 0.5 & 0 \\
\hline Halophytic coastal vegetation series & 1 & 0.3 & 1 & 0 & 1 & 0.3 \\
\hline $\begin{array}{l}\text { Meso-Mediterranean on nutrient soil rich edapho- } \\
\text { hygrophilous geoseries }\end{array}$ & 0.8 & 0.8 & 1 & 1 & 0.8 & 0.8 \\
\hline Meso-Mediterranean on nutrient soils rich series & 0.2 & 0 & 1 & 0 & 0.1 & 0 \\
\hline $\begin{array}{l}\text { Meso-Mediterranean on sandy siliceous soils } \\
\text { edaphohygrophilous series }\end{array}$ & 0.1 & 0 & 0 & 0 & 0.1 & 0 \\
\hline Meso-Mediterranean semiarid series & 0.2 & 0.3 & 0 & 0 & 0.3 & 0.3 \\
\hline $\begin{array}{l}\text { Meso-Thermo-Mediterranean meso-halophytic } \\
\text { edaphohygrophilous series }\end{array}$ & 0.7 & 0.3 & 1 & 1 & 0.6 & 0.2 \\
\hline $\begin{array}{l}\text { Meso-Upper-Mediterranean subhumid \& humid on } \\
\text { nutrient soils rich edaphohygrophilous series }\end{array}$ & 0.3 & 0.1 & 1 & 1 & 0.3 & 0 \\
\hline $\begin{array}{l}\text { Meso-Upper-Mediterranean subhumid \& humid on } \\
\text { nutrient soils rich edaphohygrophilous series }\end{array}$ & 0.3 & 0.1 & 1 & 1 & 0.3 & 0 \\
\hline $\begin{array}{l}\text { Meso-Upper-Mediterranean-low limestone-dolomit- } \\
\text { ic edaphoxerophilous series }\end{array}$ & 0.2 & 0 & 1 & 0 & 0.1 & 0 \\
\hline $\begin{array}{l}\text { Oro-Mediterranean on nutrient rich soils rich } \\
\text { edaphohygrophilous microgeoseries }\end{array}$ & 0.6 & 0.5 & 1 & 1 & 0.5 & 0.4 \\
\hline Oro-Mediterranean on nutrients rich soils series & 0.3 & 0 & 1 & 0 & 0.3 & 0 \\
\hline Oro-Mediterranean on siliceous soils series & 0.3 & 0.3 & 1 & 0 & 0.3 & 0.3 \\
\hline Salt marshes \& salinas vegetation series & 0.4 & 0.1 & 1 & 0 & 0.4 & 0.1 \\
\hline $\begin{array}{l}\text { Subsaline marls polyteselar edaphoxerophilous vege- } \\
\text { tation complex series }\end{array}$ & 0.2 & 0.9 & 1 & 1 & 0.1 & 0.9 \\
\hline $\begin{array}{l}\text { Thermo-Mediterranean dry \& subhumid on nutri- } \\
\text { ent soils rich series }\end{array}$ & 0 & 0.8 & 0 & 1 & 0 & 0.8 \\
\hline $\begin{array}{l}\text { Thermo-Mediterranean meso-halophytic edaphohy- } \\
\text { grophilous microgeoseries }\end{array}$ & 0 & 0.8 & 0 & 1 & 0 & 0.8 \\
\hline $\begin{array}{l}\text { Thermo-Mediterranean on nutrient rich soils rich } \\
\text { edaphohygrophilous geoseries }\end{array}$ & 0 & 0.3 & 0 & 0 & 0 & 0.3 \\
\hline $\begin{array}{l}\text { Thermo-Mediterranean on nutrient rich soils rich } \\
\text { edaphohygrophilous geoseries }\end{array}$ & 0 & 0.4 & 0 & 0 & 0 & 0.4 \\
\hline Thermo-Mediterranean semiarid \& arid costal series & 0 & 0.2 & 0 & 0 & 0 & 0.2 \\
\hline Thermo-Mediterranean semiarid series & 0 & 0.1 & 0 & 0 & 0 & 0.1 \\
\hline Thermo-Mediterranean semiarid-arid series & 0 & 0.1 & 0 & 0 & 0 & 0.1 \\
\hline Thermo-Mediterranean semiarid-dry series & 0.1 & 0.1 & 0 & 0 & 0.1 & 0.1 \\
\hline $\begin{array}{l}\text { Thermo-Mediterranean hyper-halophytic edaphohy- } \\
\text { grophilous microgeoseries }\end{array}$ & 0.2 & 0.1 & 1 & 1 & 0.1 & 0 \\
\hline Thermo-Mediterranean semiarid riparian geoseries & 0.1 & 0 & 0 & 0 & 0.1 & 0 \\
\hline Thermo-Mediterranean-Low semiarid series & 0.2 & 0 & 1 & 0 & 0.1 & 0 \\
\hline $\begin{array}{l}\text { Thermo-Meso-Mediterranean edaphohygrophilous } \\
\text { series }\end{array}$ & 0.2 & 0.1 & 1 & 1 & 0.1 & 0 \\
\hline $\begin{array}{l}\text { Thermo-Meso-Mediterranean edaphohygrophilous } \\
\text { series }\end{array}$ & 0 & 0.1 & 0 & 1 & 0 & 0 \\
\hline $\begin{array}{l}\text { Thermo-Meso-Mediterranean on nutrient rich soils } \\
\text { rich edaphohygrophilous series }\end{array}$ & 0 & 0.1 & 0 & 1 & 0 & 0 \\
\hline Thermo-Meso-Mediterranean series & 0 & 0.1 & 0 & 1 & 0 & 0 \\
\hline $\begin{array}{l}\text { Upper-Mediterranean dry-sub-humid on nutrient } \\
\text { rich soils series }\end{array}$ & 0.1 & 0.1 & 1 & 1 & 0 & 0 \\
\hline $\begin{array}{l}\text { Upper-Meso-Mediterranean on nutrient rich soils } \\
\text { rich edaphohygrophilous series }\end{array}$ & 0.1 & 0.1 & 1 & 1 & 0 & 0 \\
\hline $\begin{array}{l}\text { Upper-Meso-Mediterranean dry-sub-humid on } \\
\text { siliceous soils edaphohygrophilous series }\end{array}$ & 0.1 & 0 & 1 & 0 & 0 & 0 \\
\hline Upper-Meso-Mediterranean limestone series & 0.1 & 0 & 1 & 0 & 0 & 0 \\
\hline $\begin{array}{l}\text { Upper-Meso-Mediterranean on siliceous soils ripar- } \\
\text { ian geoseries }\end{array}$ & 0.1 & 0 & 1 & 0 & 0 & 0 \\
\hline Upper-Meso-Mediterranean siliceous soils Series & 0.1 & 0 & 1 & 0 & 0 & 0 \\
\hline $\begin{array}{l}\text { Upper-Meso-Mediterranean sub-humid \& humid } \\
\text { on nutrients rich soils series }\end{array}$ & 0.1 & 0 & 1 & 0 & 0 & 0 \\
\hline
\end{tabular}

expressed by pedodiversity, lithodiversity, and variability of elevation, the higher should be the value of vegetation series to represent the vegetation diversity of a land system. The aim of this paper was to test such predictivity by a case study. The test has been worked out by extending the concepts of $\alpha$ and $\beta$ diversity from that of species to that of vegetation series and to some geological features, such as pedotypes, lithotypes, and DEM. Pedodiversity, i.e. the diversity of pedotypes, received particular attention in geodiversity studies (Gray 2004) (e.g. Ibáñez et al. 1990, 1994, 1995, 2013; Petersen et al. 2010; 
Ibáñez \& Effland 2011; Ibáñez \& Bockheim 2013; Ibáñez \& Feoli 2013) and was already suggested by Ibáñez et al. (2014) as a factor that could help in explaining the plant species richness-area relationships. On the basis of simple and partial correlation $\alpha$ diversity based on vegetation series resulted highly predictive mainly with respect to the pedodiversity of the watersheds, in fact by removing the effect of pedodiversity the correlation between the extent of the watersheds and $\alpha$ vegetation diversity loses its significance. By removing the effects of lithodiversity and that of the standard deviation of elevation the correlation $\alpha$ vegetation diversity-pedodiversity and $\alpha$ vegetation diversity-area remains significant.

On the basis of Mantel's test $\beta$ vegetation diversity based on vegetation series is significantly predictive with respect to the $\beta$ diversity in terms of DEM and pedotypes, but not in terms of lithotypes. This would confirm that the combination of vegetation series of the land system of Almeria is more sensitive to factors affecting the microclimate (such elevation) than to edaphic factors, with aridity being an overwhelming factor. For calculating the similarity, the Simpson's index has been used because the data matrices of vegetation diversity, pedodiversity, and lithodiversity are significantly nested, i.e. the set of features of the watershed with more features tends to include the set of features of watersheds with less features.

The use of the Simpson's index to classify the watersheds according to vegetation series allows to separate the two largest watersheds as "seeds" of two patterns of nestedness, that would be remained hidden by the use of an index that does not consider the nestedness in the formula. One set of watersheds is draining and/or clearly gravitating on the Eastern coast and one set is draining on the Southern coast.

The classification in these subsystems of watersheds, that are significant on the basis of the vegetation series distribution, could have the following explanations: (i) the Southern shoreline is a little less arid than that the Eastern coast (AEMET 2011) although the Tabernas Desert (included in watershed 302 that belongs to the set of watersheds gravitating on the Eastern coast), the driest spot in Western Europe, drains South; (ii) Some of the larger southern basins that born from the southern slopes of Sierra Nevada (the highest mountain range in Almería), includes more plant communities and pedotypes typical of the high mountain, unlike what happens in the eastern side of the study area; (iii) the southern shoreline is rich in Ibero-Mauritanian endemic species, whereas these disappear eastward (Villalobos-Megía 2003; Simón 2005), and thus some idiosyncratic vegetation series are different; (iv) the Eastern coast is idiosyncratic by the presence of several types of volcanic rocks, including old volcanos capped cones reef limestones (Simón 2005).

\section{Conclusions}

We have to admit that the description of a land system by vegetation series could be considered rough, the level of abstraction is high with respect to the actual vegetation and certainly the corresponding maps would represent only potential vegetation. However the results of this paper show that vegetation series are suitable tools to investigate the complex relationships between vegetation diversity and the environmental heterogeneity of land systems defined in different ways. Vegetation series showed to be capable to discriminate between factors that would influence their $\alpha$ diversities, i.e. their richness in OGUs and that would influence their $\beta$ diversity, i.e. their qualitative combinations in OGUs. The data analysis of the land system of Almeria proves once again the importance of the area and of environmental heterogeneity expressed by pedodiversity to define a diversity: smaller watersheds have "statistically" less features than larger watershed and at parity of the extent more heterogeneous watersheds in terms of pedodiversity tend to have statistically more vegetation series than the less heterogeneous watersheds. The analysis of $\beta$ diversity of the watersheds based on an index of similarity, that keeps into consideration the nestedness effects on similarity, has proved the significant existence of two pattern of nestedness each one associated to one of the two most large watersheds of the area. We conclude by suggesting that vegetation series are useful conceptual tools to investigate on the biodiversity of land system both in terms of $\alpha$ and $\beta$ diversity. The vegetation series have the inherent "phytosociological key" to access to databases of plant associations and from them to biological floras that would allow the land system descriptions at different hierarchical scales of space and knowledge. Therefore our suggestion is that the vegetation series is a concept with high value of synthesis in the knowledge domain of vegetation system and worth to be used in biodiversity analysis of land systems.

\section{Acknowledgments}

Many thanks are given to Carlo Blasi for comments on the manuscript and to Janos Podani for suggesting references on nestedness concept. The last author acknowledges the University of Trieste for supporting his research on "Data analysis of complex systems". 


\section{Disclosure statement}

No potential conflict of interest was reported by the authors.

\section{References}

AEMET (Agencia Estatal de Meteorología). 2011. Iberian climate atlas. Spain: Ministerio de Medio Ambiente y Medio Rural y Marino. Available: http://www.aemet.es/es/serviciosclimaticos/ datosclimatologicos/atlas_climatico.

Aguilar-Ruiz J, Martín-Peinado F, Sierra-Aragón M, Ortíz-Silla R, Oyonarte C. 2004. Mapa digital de suelos: Provincia de Almería [Digital soil map: Almería province (Spain)]. Tragsa, Madrid, Spain: Dirección General para la Biodiversidad. Ministerio de Medio Ambiente. NIPO 311-04-082-5.

Almeida-Neto M, Frensel DMB, Ulrich W. 2012. Rethinking the relationship between nestedness and beta diversity: A comment on Baselga (2010). Global Ecol Biogeogr 21: 772-777.

Altobelli A, Bressan E, Feoli E, Ganis P, Martini F. 2007. Improving knowledge of urban vegetation by applying GIS technology to existing databases. Appl Veg Sci 10(2): 203-210.

Anderberg MR. 1973. Cluster Analysis for Applications. New York: Academic Press.

Anderson MJ, Crist TO, Chase JM, Vellend M, Inouye BD, Freestone AL, et al. 2011. Navigating the multiple meanings of $\beta$ diversity: A roadmap for the practicing ecologist. Ecol Lett 14: 19-28.

Atmar W, Patterson BD. 1993. The measure of order and disorder in the distribution of species in fragmented habitat. Oecologia 96: 373-382.

Atmar W, Patterson BD. 1995. The nestedness temperature calculator: A visual basic program, including 294 presenceabsence matrices. New Mexico: AICS Res. Inc., University Park, and Chicago: The Field Mus. Available: http://aicsresearch.com/nestedness/tempcalc.html.

Biondi E. 2011. Phytosociology today: Methodological and conceptual evolution. Plant Biosyst 145: 19-29.

Blasi C, editor. 2010. La vegetazione d'Italia con carte delle serie di vegetazione in scala 1:500000 [Vegetation of Italy with maps of vegetation series at scale 1:500000]. Roma: Palombi Editori.

Blasi C, Capotorti G, Copiz R, Guida D, Mollo B, Smiraglia D, et al. 2014. Classification and mapping of the ecoregions of Italy. Plant Biosyst 148: 1255-1345.

Blasi C, Capotorti G, Frondoni R. 2005. Defining and mapping typological models of the landscape scale. Plant Biosyst 139: $155-163$.

Blasi C, Carranza ML, Frondoni R, Rosati L. 2000. Ecosystem classification and mapping. A proposal for Italian landscapes. Appl Veg Sci 3: 233-242.

Blasi C, Filibeck G, Frondoni R, Rosati L, Smiraglia D. 2004. The map of vegetation series of Italy. Fitosociologia 41: 21-25.

Brandt CJ, Thornes JB, editors. 1996. Mediterranean desertification and land use. Chichester: John Wiley \& Sons.

Burba N, Feoli E, Malaroda M. 2008. MATEDIT: A software tool to integrate information in decision-making processes. In: Neve R, Barretta JW, Mateus M, editors. Perspectives on integrated coastal management in South America. Lisboa: IST PRESS. pp. 123-127.

Cooker RV, Warren A. 1973. Geomorphology in deserts. Berkley: University of California Press.

Dragan M, Duriavig M, Feoli E, Fernetti M, Lourenco N, Machado C. 2007. Order and chaos in landscape: The role of suitabilty maps to plan sustainable development. Ecol Quest 8: 77-86.

FAO. 1998. World reference base for soil resources. Rome: FAO, World Soil Resources Report. p. 84.
Farina A. 2000. Landscape ecology in action. Dordrecht: Kluwer Academic.

Feoli E. 2012. Diversity patterns of vegetation systems from the perspective of similarity theory. Plant Biosyst 146: 797-804

Feoli E, Gallizia Vuerich L, Ganis P, Zerihun W. 2009. A classificatory approach integrating fuzzy set theory and permutation techniques for land cover analysis: A case study on a degrading area of the Rift Valley, Ethiopia. Comm Ecol 10: 53-64.

Feoli E, Ganis P, Ricotta C. 2013. Measuring diversity of environmental systems. In: Ibáñez J, Bockheim J, editors. Pedodiversity. Boca Raton, FL: CRC Press, Taylor \& Francis Group. pp. 29-58.

Feoli E, Ganis P, Zerihun W. 1988. Community niche an effective concept to measure diversity of gradients and hyperspace. Coenoses 3: 31-34.

Feoli E, Ganis P, Zuccarello V, Venanzoni R. 2011. Towards a framework of integrated knowledge of terrestrial vegetation system: The role of databases of phytosociological relevés. Plant Biosyst 145(1): 74-84.

Feoli E, Orlóci L. 2011. Can similarity theory contribute to the development of a general theory of the plant community? Comm Ecol 12(1): 135-141.

Feoli E, ZuccarelloV. 1996. Spatial pattern of ecological processes: The role of similarity in GIS applications for landscape analysis. In: Fisher M, Scholten H, Unwin D, editors. Spatial analytical perspectives on GIS. London: Taylor and Francis. pp. $175-185$.

Gray M. 2004. Geodiversity: Valuating and conserving abiotic nature. Norfolk: Wiley.

Ibáñez J, Bockheim J. 2013. Pedodiversity. Boca Raton, FL: CRC Press, Taylor \& Francis Group.

Ibáñez J, Caniego J, García-Álvarez A. 2005b. Nested subset analysis and taxa-range size distributions of pedological assemblages: Implications for biodiversity studies. Ecol Model 182: 239-256.

Ibáñez J, Caniego J, San-José F, Carrera C. 2005a. Pedodiversityarea relationships for islands. Ecol Model 182: 257-269.

Ibáñez JJ, De-Alba S, Bermúdez FF, García-Álvarez A. 1995. Pedodiversity: Concepts and measures. Catena 24: 215-232.

Ibáñez JJ, Effland WR. 2011. Toward a theory of island pedogeography: Yesting the driving forces for pedological assemblages in archipelagos of different origins. Geomorphology 135: 215-223.

Ibáñez J, Feoli E. 2013. Global relationships of pedodiversity and biodiversity. Vadose Zone J 12(3). doi: http://dx.doi.org/10.2136/vzj2012.0186.

Ibáñez J, Jiménez-Ballesta R, García-Álvarez A. 1990. Soil landscapes and drainage basins in Mediterranean mountain areas. Catena 17: 573-583.

Ibáñez JJ, Pérez-González A, Jiménez-Ballesta R, Saldaña A. 1994. Evolution of fluvial dissection landscapes in Mediterranean environments. Quantitative estimates and geomorphological, pedological and phytocenotic repercussions. Z Geomorphol 38: 105-119.

Ibáñez J, Pérez-Gomez R, Oyonarte C, Brevik EC. 2015. Are there arid lands soilscapes in Southwestern Europe? Land Degrad Develop. 26: 853-862.

Ibáñez JJ, Vargas RJ, Vázquez-Hoehne A. 2013. State of the art and future challenges. In: Ibáñez J, Bockheim JG, editors. Pedodiversity. Boca Raton, FL: CRC Press. pp. 1-28.

Ibáñez J, Zuccarello V, Ganis P, Feoli E. 2014. Pedodiversity deserves attention in plant biodiversity research. Plant Biosyst 148: $1112-1116$

Ibrahim L, Vogiatzakis IN, Incerti G, Feoli E. 2015. The use of fuzzy plant species density to indicate the effects of land cover changes on biodiversity. Ecol Ind 57: 149-158. 
Junta de Andalucía. 2015. Agencia de Innovación y Desarrollo de Andalucía 2015. IDEA Portal. Available: http://www. agenciaidea.es/.

Kleinbaum DG, Kupper LL, Muller KF. 1988. Applied regression analysis and other multivariable methods. Boston, MA: PWS.

Loidi J, Fernández-González F. 2012. Potential natural vegetation: Reburying or reboring? JVeg Sci 23: 596-604.

Mantel N. 1967. The detection of disease clustering and a generalized regression approach. Cancer Res 27: 209-220.

Mantel N, Valand RS. 1970. A technique of nonparametric multivariate analysis. Biometrics 26: 547-558.

Manthey M, Fridley JD. 2009. Beta diversity metrics and the estimation of niche width via species co-occurrence data: Reply to Zeleny. J Ecol 97: 18-22.

Olivero J, Marquez AL, Real R. 2013. Integrating fuzzy logic and statistics to improve the reliable delimitation of biogeographic regions and transition zones. Syst Biol 62(1): 1-21.

Ollier CD. 1976. Catenas in different climates. In: Derbyshire E, editor. Geomorphology and climate. Chichester: Wiley. pp. 137-170.

Omernik JM, Bailey RG. 1997. Distinguishing between watersheds and ecoregions. J Am Water Resour As 33: 935-949.

Ottaviano GIP, Pinelli D, Maignan CJ, Rullani F. 2003. BioEcological Diversity vs. Socio-Economic Diversity:A Comparison of Existing Measures (January 2003). FEEMWorking Paper No. 13.2003. Available at SSRN: http://ssrn.com/abstract $=389043$ or http://dx.doi.org/10.2139/ssrn.389043.

Patterson BD. 1990. On the temporal development of nested subsets patterns of species composition. Oikos 59:330-342.

Petersen A, Gröngröft A, Miehlich G. 2010. Methods to quantify the pedodiversity of $1 \mathrm{~km}^{2}$ areas. Results from southern African drylands. Geoderma 155: 140-146.

Pillar VD. 1996. A randomization-based solution for vegetation classification and homogeneity testing. Coenoses 11:29-36.

Pignatti S. 1980. Reflections on the phytosociological approach and the epistemological basis of vegetation science. Vegetatio 42: 181-185.

Podani J. 2000. Introduction to the exploration of multivariate biological data. Leiden: Backhuys Publishers.

Podani J, Ricotta C, Schmera D. 2013. A general framework for analyzing beta diversity, nestedness and related community-level phenomena based on abundance data. Ecol Complex 15: 52-61.

Podani J, Schmera D. 2011. A new conceptual and methodological framework for exploring and explaining pattern in presenceabsence data. Oikos 120: 1625-1638.

Podani J, Schmera D. 2012. A comparative evaluation of pairwise nestedness measures. Ecography 35: 889 900.

Podani J, Schmera D. 2016. Once again on the components of pairwise beta diversity. Ecol Inform 32: 63-68.

Potyondy JP, Geier TW. 2011. Watershed condition classification technical guide. FS-978. U.S. Department of Agriculture, Forest Service. Available: http://www.fs.fed.us/publications/ watershed/watershed_classification_guide.pdf

Puigdefábregas J, Mendizabal T. 1998. Perspectives on desertification: Western Mediterranean. J Arid Environ 9: 209-224.

Rao CR. 1982. Diversity and dissimilarity measurements: A unified approach. Theor Popul Biol 21:24 43.

Rao AR, Srinivas VV. 2008. Regionalization of watersheds. An approach based on cluster analysis. New York: Springer Science \& Business Media.

Riemer N, West M. 2013. Quantifying aerosol mixing state with entropy and diversity measures. Atmos Chem Phys 13: 11423 11439.
Rivas-Martínez S. 2005. Notions on dynamic-catenal phytosociology as a basis of landscape science. Plant Biosyst 139: 135-144.

Rivas-Martínez S. 2007. Mapa de series,geoseries y geopermaseries de vegetation de Espana [Map of vegetation series, geoseries, and geopermaseries of/(in) Spain]. Leon, Spain: Itineraria Geobotanica. 17, 434pp.

Saldaña A. 1997. Complexity of soils and soilscape patterns on the southern slopes of the Ayllón Range, Central Spain. A GIS-assisted modelling approach. Enschede: $\mathrm{PhD}$ thesis, Publication Nr. 49, ITC.

Shannon CE, Weaver W. 1949. The mathematical theory of communication. Urbana: University of Illinois Press.

Simón M, editor. 2005. Almería: factores formadores y suelos [Almería: Soils and soil forming factors]. Almería, Spain: Editorial Universidad de Almería.

Simpson GG. 1943. Mammals and the nature of continents. Am J Sci 241: 1-31.

Strahler AN. 1957. Quantitative analysis of watershed geomorphology. Trans Am Geophys Un 38: 913-920.

Troch PA, Carrillo GA, Heidbüchel I, Rajagopal S, Switanek M, Volkmann THM, Yaeger M. 2008. Dealing with landscape heterogeneity in watershed hydrology: A review of recent progress toward new hydrological theory. Geogr Compass 3(1): 375-392.

Tuomisto H. 2011. Commentary: Do we have a consistent terminology for species diversity? Yes if we choose to use it. Oecologia 167: 903-911.

Turner MC. 1990. Spatial and temporal analysis of landscape patterns. Lands Ecol 4(1): 21-30.

Ulrich W, Almeida-Neto M. 2012. On the meanings of nestedness: Back to the basics. Ecography 35: 1-7.

Ulrich W, Almeida-Neto M, Gotelli N. 2009. A consumer's guide to nestedness analysis. Oikos 118: 3-17.

van der Maarel E. 1975. The Braun-Blanquet approach in perspective. Vegetatio 30: 213-219.

van der Maarel E, editor. 2005. Vegetation ecology. Oxford: Blackwell. 395 pp.

Villalobos-Megía MA. 2003. Geology of the arid zone of Almeria, South East Spain. An educational field guide. State water Company for the Southern Basin SA. ACUSUR. Available: http://www.juntadeandalucia.es/medioambiente/web/ ContenidosOrdenacion/red_informacion_ambiental/PDF/ Geodiversidad/Geology_of_the_arid_zone_of_Almeria/Front page.pdf.

Warren CE. 1979. Toward classification and rationale for watershed management and stream protection. EPA 600/3 79059. Corvalis OR 97330: Environmental Research Laboratories.

Wen Y, Khosrowpanah S, Heitz L. 2011. Land cover change of watersheds in Southern Guam from 1973 to 2001. Environ Monit Assess 179: 521-529.

Wessa P. 2015. Free statistics software. Office for Research Development and Education, version 1.1.23-r7. Available: http://www.wessa.net/.

Whittaker RH. 1960. Vegetation of the Siskiyou mountains, Oregon and California. Ecol Monogr 30: 279-338.

Whittaker RH. 1975. Communities and ecosystems. New York: Macmillan.

Whittaker RH. 1977. Evolution of species diversity in land communities. In: Hecht MK, Steere WC, Wallace B, editors. Evolutionary biology. Vol. 10. New York: Plenum. pp. 1-67.

Wishart D. 1969. An algorithm for hierarchical classifications. Biometrics 25: 165-170. 